\title{
Size composition and fecundity of the rock crab Grapsus grapsus (Linnaeus, 1758) in the islands of Navachiste Bay, Sinaloa, Mexico
}

\author{
YECENIA GUTIERREZ RUBIO ${ }^{1}$, JUAN FRANCISCO ARZOLA GONZALEZ ${ }^{1}$, JORGE SAUL \\ RAMIREZ PEREZ ${ }^{1}$, GUILLERMO RODRIGUEZ DOMINGUEZ ${ }^{1}$, RAUL PEREZ GONZALEZ ${ }^{1}$, \\ ANDRES MARTIN GONGORA GOMEZ ${ }^{2}$, MARIA CANDELARIA VALDEZ PINEDA ${ }^{1}$, JESUS \\ MANUEL DIAZ GAXIOLA ${ }^{3}$, REBECA SANCHEZ CARDENAS ${ }^{1}$ AND LUIS ANTONIO \\ SALCIDO GUEVARA ${ }^{1}$ \\ ${ }^{1}$ Faculty of Marine Sciences, Autonomous University of Sinaloa. A. P. 610, Mazatlan, Sinaloa, Mexico \\ ${ }^{2}$ National Polytechnic Institute, Interdisciplinary Research Centre for Regional Integral Development, Unit Sinaloa \\ Aquaculture Department, CP 81101. Blvd. Juan de Dios Batiz No. 250, Col. San Juachin, Guasave, Sinaloa, Mexico \\ ${ }^{3}$ Technological National of Mexico, Laboratory of Ecology, Blvd. Juan de Dios Batiz s/n, Los Mochis, Sinaloa, Mexico \\ e-mail:farzola@uas.edu.mx
}

\begin{abstract}
The present study analysed the size composition and fecundity of Grapsus grapsus (Linnaeus, 1758) in the intertidal regions of Guasayeye, La Ventana and San Lucas islands in Navachiste Bay, Sinaloa, Mexico. Samples were collected from November 2017 to October 2018 with a bimonthly periodicity and sampling stations were established in each island. Crab samples were collected randomly at nocturnal low tide. Sex of the crabs was determined and carapace width $(\mathrm{CW})$, length $(\mathrm{L})$ and height $(\mathrm{H})$ in $\mathrm{mm}$, and their weight (W) in $\mathrm{g}$ were measured. Biometric correlations were performed. Fecundity was estimated in gravid females. The highest percentage of capture for females was 53.3\% whereas for males was $46.7 \%$ and the sex ratio was 1.15:1. The highest percentage was in San Lucas Island (41.4\%) and the lowest in La Ventana (27.7\%). Maximum CW (69.3 mm) and weight (137.5 g) were recorded in San Lucas. Island, while the lowest CW $(9.3 \mathrm{~mm})$ and weight $(0.5 \mathrm{~g})$ were recorded in Guasayeye Island. No significant difference in size $(\mathrm{CW}$ and $\mathrm{W})$ were observed between sexes or between islands. The average fecundity for female was 9,245 eggs. A high biometric correlation was obtained $\left(\mathrm{r}^{2}=0.98\right)$ between the morphometric variables and G. grapsus was found to have an isometric growth.
\end{abstract}

Keywords: Fecundity, Grapsus grapsus, Navachiste islands, Population, Rock crab, Size composition

The coast of Sinaloa and its natural resources have been insufficiently studied (Flores-Campana et al., 2003). In this region, there are over 400 islands, which are classified as cliffs, cays, bars, points, reefs, rocks, islands and islets which represent almost $45 \%$ of the insular bodies that are within the Gulf of California (Flores-Campana et al., 2003). The islands of Sinaloa are considered as continental due to their proximity to the coastal zone or within semi-enclosed coastal ecosystems of bays viz., Topolobampo, Navachiste, Santa Maria, AltataEnsenada del Pabellon and Mazatlan (Anonimo, 1988). Sinaloa islands are part of a protected natural area which is currently identified as the Flora and Fauna Protection Area of the Gulf of California Islands (DOF 07/06/2000). Therefore, adequate knowledge of the communities that inhabit these environments is necessary, especially in those where anthropogenic activities have not generated significant changes in their composition (Flores-Campana et al., 2007). In these insular ecosystems due to their easy accessibility, some species of crustaceans are captured in shallow waters or in the intertidal zones. One such species is the rock crab Grapsus grapsus (Linnaeus, 1758), which is used locally for human consumption (Arzola-Gonzalez and Flores-Campana, 2008) and as bait for fishing (Arzola-Gonzalez et al., 2010; Gutierrez-Rubio et al., 2018). G. grapsus is one of the most common intertidal species in the islands of Navachiste Bay, Sinaloa. This species, belonging to the Grapsidae family, is distributed in the Eastern Pacific in Cedros Island, on the west coast of Baja California, Rocas Alijos and the Revillagigedo islands, Mexico to the Talcahuano Bay, Chile; including the Galapagos islands, Clipperton, Malpelo and Juan Fernandez (Hendrickx et al., 2005). In the equatorial Atlantic Ocean, it is distributed in the San Pedro and San Paul islands (Freire et al., 2010).

Most of the work carried out on this species deals with taxonomic and distribution aspects (Hendrickx et al., 2005, Arzola Gonzalez et al., 2010). Recently, BarcenasGutierrez and Jauregui-Velazquez (2017) analysed the 
social and reproductive behaviour of G. grapsus in the intertidal region of Puerto Vallarta, Jalisco. However, there are practically no studies on morphometric characters (Gutierrez-Rubio et al., 2018) and fecundity (Teschima et al., 2007) of G. grapsus from this area. This is a situation very different from that observed in other decapod crustaceans, where various biological aspects have been analysed, such as in lobsters, Panulirus spp. (Arzola-Gonzalez et al., 2011); penaeid shrimps, Penaeus spp. (Aragon-Noriega et al., 2017) and crabs, Callinectes spp. (Rodriguez-Dominguez et al., 2012).

The present study is important because it provides basic information on the size composition and fecundity of G. grapsus, that may lead to implementation of fishing regulatory measures by the concerned authorities in Navachiste Bay, Sinaloa, Mexico.

The study area included different locations in the Guasayeye, La Ventana and San Lucas island system; which are located on the coastal area of the south-east of the Gulf of California, between $25^{\circ} 22^{\prime}$ and $25^{\circ} 35^{\prime} \mathrm{N}$ and $108^{\circ} 42^{\prime}$ and $108^{\circ} 56^{\prime} \mathrm{E}$, in Navachiste Bay, Sinaloa, Mexico.

Surveys were carried out in the study area in order to identify topographic characteristics, exposure time and area of the coast during the tidal wave. In this way, collection strategies were established in each sampling station, preferably similar location in the rocky substrate were selected and general observations were made in each island. Bimonthly samples were collected from November 2017 to September 2018. Guasayeye Island has the largest rocky beach and La Ventana Island is characterised by a narrow beach and is difficult to access due to the huge size of the rocks. San Lucas Island has two rocky areas with a sandy beach in between with small rocks and a mangrove zone (Ortiz-Arellano and Flores-Campana, 2008).

The samplings were nocturnal during the tides of syzygy and in the low tide phase. A $2 \times 20 \mathrm{~m}$ transect was used parallel to the coastline according to Freire et al. (2010), with the lower limit at low tide of each station. $G$. grapsus in intermoult stage were collected and deposited in plastic bags with seawater and ice and then transported to the laboratory in a cooler. Subsequently, the crabs were sexed based on the shape of the abdomen (which is wide in females and narrow in males), in addition to the presence of birramous pleopods in females and uniramous in males.

Carapace width (CW), length (L) and height (H) of the crabs were measured with a digital vernier caliper $(0.01$ $\mathrm{mm}$ ) and their respective fresh weight (W) using a digital scale $(0.1 \mathrm{~g}$ sensitivity) in intermoult stage. The form of growth was verified based on the relation between the length of the cephalothorax and weight, and also between the lengths. Moreover, the coefficient of determination $\left(\mathrm{r}^{2}\right)$ between the morphometric relationships was calculated, by means of the following equations:

$y=a+b x, y=a x b,($ Ricker, 1975).

where, $\mathrm{y}=$ corresponds to $\mathrm{CW}, \mathrm{L}$ or $\mathrm{W} ; \mathrm{a}=$ ordered to the origin; $\mathrm{b}=$ slope; $\mathrm{x}=\mathrm{CW}, \mathrm{L}$ or $\mathrm{W}$

The Student's $t$ - test was applied to the value of the exponent (b) of the equation obtained from the biometric relationship between length and weight. Once the values were transformed into logarithms and under the assumption that if "b" equals three (Zar, 2009), it was assumed that the G. grapsus organisms grow isometrically.

Fecundity was estimated by gravimetric method (Bagenal et al., 1978; Escamilla-Montes et al., 2013) in which all gravid females were used. Once the measurements and the corresponding weight of each specimen were recorded, the egg mass was removed For each female, the eggs were weighed in preweighed aluminum dishes to get the wet weight of the egg mass.

For each roe, three subsamples of $0.001 \mathrm{~g}$ were taken at random and placed in petridishes and counted under a stereoscopic microscope. Then, the average of the three subsamples were calculated. Finally, this average was extrapolated with respect to the dry weight of the roe, thus obtaining the total estimate of eggs (fecundity) for each gravid female.

Normality tests (Kolmogorov-Sminorv test) and homoscedasticity (Bartlet test) were performed on the $\mathrm{CW}$ and $\mathrm{W}$ data, and Kruskal-Wallis test was performed by ranges. To estimate the difference between the width and weight between sexes, Student's t test was conducted. Student's t test was used to estimate the value of the slope (b) of the biometric relationship of length and weight. In all cases, a significance level of $(\alpha) 0.05$ was used (Zar, 2009) and the statistical package, StaSoft V7.0 (StaSoft, 2004) was used.

In total, 198 organisms were analysed, out of which 106 were females (53.3\%) and 92 males (46.7\%), with female to male ratio of 1.15:1. Among the study loations, the highest catch percentage was in San Lucas (41.4\%) and the lowest in La Ventana (27.7\%). The population of G. grapsus reached a maximum width of $69.3 \mathrm{~mm}$ and maximum weight of $137.5 \mathrm{~g}$ which was recorded in San Lucas Island, while the lowest size in terms of width was of $9.3 \mathrm{~mm}$ and weight of $0.5 \mathrm{~g}$ was recorded in Guasayeye Island (Table 1). 
Table 1. Maximum, minimum, mode, mean and standard deviation (S.D.) of carapace width (CW), length (L) and height $(\mathrm{H})$ and weight $(\mathrm{W})$ of G. grapsus in the islands of Navachiste Bay

\begin{tabular}{lcccc}
\hline & $\mathrm{CW}(\mathrm{mm})$ & $\mathrm{L}(\mathrm{mm})$ & $\mathrm{H}(\mathrm{mm})$ & $\mathrm{W}(\mathrm{g})$ \\
\hline Max. & 69.3 & 61.1 & 35.4 & 137.5 \\
Min. & 9.3 & 8.4 & 3.9 & 0.5 \\
Mode & 15.0 & 12.3 & 6.2 & 0.9 \\
Mean & 18.0 & 14.6 & 8.1 & 4.9 \\
\pm S.D. & 8.4 & 7.4 & 4.6 & 13.8 \\
\hline
\end{tabular}

No significant differences were found in $\mathrm{CW}$ and $\mathrm{W}$ between males and females ( $\mathrm{t}$-Student test, $\mathrm{p}>0.05$ ). Among the islands, when comparing the sizes in terms of $\mathrm{CW}$ of $G$. grapsus, they did not follow a normal distribution (Kolmogorov-Sminorv, $\mathrm{p}<0.05$ ). Hence the nonparametric test, Kruskal-Wallis test by ranges was carried out, where the sizes of G. grapsus in terms of CW did not indicate significant difference between the rock crabs of Guasayeye, La Ventana and San Lucas islands.

For comparative purposes, W (g) of the rock crabs between the islands were also statistically analysed. They did not present a normal distribution (KolmogorovSminorv, $\mathrm{p}<0.05$ ), except for the population from Isla La Ventana (Kolmogorov-Sminorv, $p>0.05$ ). So the homoscedasticity test was omitted, opting for a nonparametric test (Kruskal-Wallis test by ranges), resulting in nonsignificant differences in weight between the organisms in the three islands. Linear equations were obtained when correlating the morphometric variables of width, length and height. In all cases, the correlation coefficients $\left(\mathrm{r}^{2}\right)$ were above 0.98 , which indicated high dependence on the morphometric variables of the rock crabs in the islands of Navachiste Bay. When analysing correlation between the width of cephalothorax and weight, a slope (b) of 2.79 was obtained $(\mathrm{p}=0.95)$, which reveals that the population of G. grapsus presents an isometric growth (Fig. 1).

The estimation of fecundity per female of G. grapsus in the islands, recorded an average 9,245 eggs, with a maximum and minimum variation of 122,287 and 511 eggs, which coincided in San Lucas Island (Table 2).

The organisms were collected above the rocks or between craters among the rocks during night, which corroborates with the observations of Freire et al. (2010) who indicated that $G$. grapsus are most active during night. Rock crabs with larger sizes were always located above boulders and usually when they are caught by other crabs of the same species; they enter the coastal lagoon as a defense mechanism (Romero, 2003b). In addition, larger G. grapsus exhibit colour variations from olive green to

Table 2. Maximum, minimum and average of total weight of female (TW), wet weight of egg mass (EW) and fecundity (FEC) of Grapsus grapsus

\begin{tabular}{lllll}
\hline Island & & $\mathrm{TW}(\mathrm{g})$ & $\mathrm{EW}(\mathrm{g})$ & FEC (No. of eggs per female) \\
\hline Guasayeye & Max. & 8.6 & 0.169 & 16,135 \\
& Min. & & 0.024 & 648 \\
& Average & & 0.069 & 4,201 \\
\hline La Ventana & Max. & 8.3 & 0.070 & 2,800 \\
& Min. & & 0.011 & 519 \\
& Average & & 0.038 & 1,326 \\
\hline San Lucas & Max. & 87.5 & 2.505 & 122,287 \\
& Min. & & 0.014 & 511 \\
& Average & & 0.551 & 22,208 \\
\hline
\end{tabular}

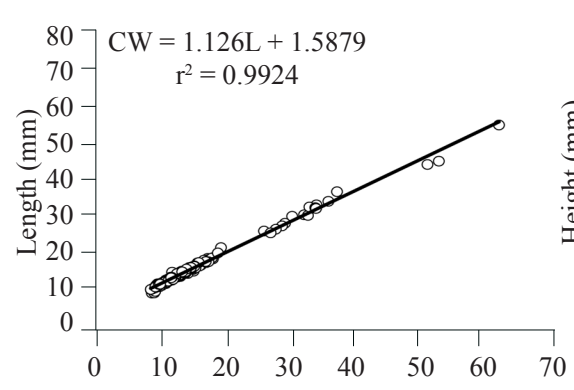

(a)

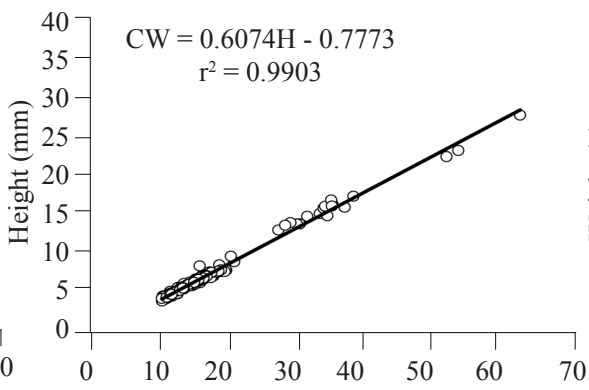

(b)

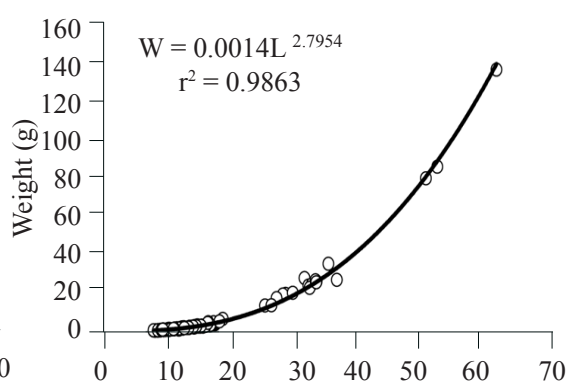

(c)

Fig. 1. Biometric relationships of (a) width-length, (b) width-height (mm) and (c) length-weight (g) of G. grapsus in the islands of Navachiste Bay 
red orange, as reported by Romero (2003a), Fernandez Sanchez (2012) and Freire et al. (2010), who attributed the colour variations to reproductive stages and aggressive nature.

The larger sized rock crabs were collected in San Lucas over rocky habitats with abundant bivalve molluscs species viz., Crassostrea corteziensis, Magallan gigas and Saccostrea palmula, while in Guasayeye Island, smaller sized juvenile G. grapsus were dominating which were found associated with the gastropod Cerithium stermuscarum. Crabs of small sizes were found on the island La Ventana, which has smaller areas of rocks. Furthermore, it was observed that rock crabs were associated with crustacean cirripedes (barnacles) and macroalgae, which according to Romero (2003b) and Arteta-Bonivento (2009) are constantly depredating both groups.

The size of G. grapsus in terms of carapace width recorded in the present study was found to be lower than those reported by Brusca (1980), who recorded G. grapsus between 40 to $90 \mathrm{~mm}$ width. However, this author's collection of rock crabs corresponded to a very specific collection area i.e., islands of Navachiste Bay in the intertidal area of the Gulf of California. The islands Guasayeye, La Ventana and San Lucas covered in the present study are located within Navachiste Bay in the southern centre of the Gulf of California.

Gutierrez-Rubio et al. (2018), recorded average size of $41.4 \mathrm{~mm} \mathrm{CW}$ and $31.5 \mathrm{~g}$ weight for G. grapsus in the intertidal zone of islands of Mazatlan Bay located south of Sinaloa, which is well above those registered during the present study. It is evident that the size and weight of the population of rock crab in Navachiste Bay could be related mainly to salinity, since this bay is located in a semienclosed area that is connected to the Gulf of California by two permanent openings, where salinity varies throughout the year due to precipitation (Flores-Campana et al., 2012) and by the flow of marine currents to the lagoon system or vice versa (Sanchez-Lindoro et al., 2017). On the other hand, the islands that are located in Mazatlan Bay are completely connected to the Gulf of California, that is to say, completely marine water, where salinity of the bay are not influenced by precipitations. However, the presence of the rock crab in the intertidal region of the Guasayeye, San Lucas and La Ventana islands (Navachiste Bay) is of particular interest for studies related to these ecosystems, due to the fact that some authors have indicated greater incidence of $G$. grapsus in an intertidal rocky marine habitat (Brusca, 1997; Freire et al., 2010; Gutierrez-Rubio et al., 2018) than in a lagoon ecosystem.
In crustaceans of commercial interest, the use of length-frequency models allows analysing the structure of a population through the distribution of frequencies of mode in length and weight as in the spiny lobsters (PugaLopez et al., 2015), penaeid shrimps (Felix Ortiz et al., 2014) and brachyuran crabs (Guerrero and Arana, 2009; Peiro and Mantelatto, 2011; Rivera-Velazquez et al., 2018). Sometimes, it is convenient to use mode rather than the average for population analysis of fishery resources. As it is acknowledged that the standard measure is more common than the average; however, sometimes the mode and the average do not coincide, hence mode is a better representative than the average for any fishery evaluation.

In this study, the values of the means and mode of width, length and height of G. grapsus were very similar which imply that the morphological interpretation of the population of rock crab can be used for their fishery evaluation. Although, with respect to weight, both variables (mean and mode) were not similar. Therefore, a better population analysis of this resource in this area would be more advisable using the average than the mode in terms of weight in G. grapsus.

Estimation of fecundity per female of $G$. grapsus showed that the maximum and minimum sizes coincided with the crabs collected in San Lucas Island. The female with highest body weight (137.5 g) and egg mass weight $(2.5 \mathrm{~g})$ was observed in this island. The relationship between the lower body sizes and lower fecundity as observed in the present study in the Guasayeye, La Ventana and San Lucas islands, corroborates with the findings by Teschima et al. (2007) in G. grapsus females and in females of Macrobrachium amazonicum by AyaBaquero and Velasco-Santamaria et al. (2013), indicating that there is a direct relationship between the size of the female and the number of eggs.

Estimation of fecundity in fishing populations is of special interest in terms of the relationship between the reproductive potential of the species and the capacity for renewal of populations. In addition, it represents a basic aspect in the biological knowledge of the reproductive strategy and evolution of the population. Fecundity represents the potential reproductive capacity of an adult female, that is, the number of eggs produced during spawning; furthermore, it is closely related to the population survival capacities (Bagenal, 1978; EscamillaMontes et al., 2013). It is an important parameter for estimating the reproductive capacity and size of "future recruitment" of different crustacean species or populations (Hattori and Pinheiro, 2001). Fecundity observed in this study, was well below the one recorded by Teschima et al. (2007) for the same species and in Western Atlantic with an average fecundity of 23,873 eggs per female, as well as 
Gutierrez-Rubio (2015) in females of G. grapsus with an average of 23,354.8 eggs in the islands Lobos, Venados and Pajaros of Mazatlan Bay. The size of the abdomen recorded in the present study were also found lower than those indicated in the above studies.

In contrast to the present finding in G. grapsus, Escamilla-Montes (2013) estimated average values above one million eggs per female for commercial crabs Callinectes arcuatus and Callinectes bellicosus, which indicates that females with larger sizes have higher fecundity. Ramirez Llodra (2002) and Clores and Ramos (2013) have indicated that variations in fecundity of females are directly related to the fact that a female is spawning for the first time. The variations in fecundity of crustaceans have been attributed to the size of females, with their latitudinal distribution and with the habitats (Teschima et al., 2007; Guerrero and Arana, 2009; Freire et al., 2010; Clores and Ramos, 2013).

Results of the present study provides basic information on the size composition, morphometric relationships and fecundity of $G$. grapsus which can be useful for setting fishing regulatory measures for this important resource in the islands of Navachiste Bay.

\section{Acknowledgements}

This study is part of a doctoral degree thesis. The author thanks CONACYT for the scholarship, personnel of the Consolidated Academic Body Management of Fishing Resources (UAS-CA-2104), Jennifer Tirado Lopez for the field analyses, Jorge Elenes Lizarraga for translation of manuscript and the coastal fishermen of the Navachiste Bay.

\section{References}

Anon. 1988. Islands of the Gulf of California. Federal District: Secretariat of the Navy / National Autonomous University of Mexico, Mexico City, Mexico, 292 pp. (In Spanish).

Aragon-Noriega, E. A., Mendivil-Mendoza, J. E., AlcantaraRazo, E., Valenzuela-Quinonez, W. and Felix-Ortiz, J. A. 2017. Multi-criteria approach to estimate growth curve in the marine shrimp Penaeus vannamei, (Decapoda: Penaeidae). Crustaceana, 90(11-12): 1513-1531. DOI.org/ 10.1163/15685403-00003729.

Arteta-Bonivento, R. 2009. Crabs in the Delta Rio Rancheria, Riohacha (Colombia) (Crustacea: Deacpoda: Brachyura). Bol. Cient. Mus. Hist. Nat., 13(1): 140-152 (In Spanish).

Arzola-Gonzalez, J. F. and Flores-Campana, L. M. 2008. Alternatives for the exploitation of decapod crustaceans from the El Verde stream, Camacho, Sinaloa, Mexico. Universidad y Ciencia, 24(1): 41-48 (In Spanish).
Arzola-Gonzalez, J. F., Flores-Campana, L. M. and VazquezCervantes, A. 2010. Intertidal decapod crustaceans from the islands off the coast of Sinaloa, Mexico. Universidad $y$ Ciencia, 26(2): 179-193 (In Spanish).

Aya-Baquero, E. and Velasco-Santamaria, Y. 2013. Fecundity and fertility of Macrobrachium amazonicum (Decapoda, Palemonidae) from the Piedmont Plains of Colombia. Rev. MVZ Cordoba, 18(3): 3773-3780 (In Spanish).

Arzola-Gonzalez, J. F., Perez-Gonzalez, R., Munoz-Garcia, I., Gutierrez-Rubio, Y. and Flores-Campana, L. M. 2011 Distribution of lobster sizes Panulirus inflatus and Panulirus gracilis in the fishery of southern Sinaloa, Mexico. Rev. Lat. Rec. Nat., 7(1): 15-50 (In Spanish).

Bagenal, T. 1978. Aspects of fish fecundity. In: Methods of assessment of fish production in freshwaters. Handbook, Blackwell Scientific Publications Ltd., Oxford, UK, 98 pp.

Barcenas-Gutierrez, S. Q. and Jauregui-Velazquez, E. E. 2017. Aspects of the behaviour of Grapsus grapsus in the intertidal zone of Puerto Vallart, Jalisco, Mexico. BIOCYT., 10(37): 672-686 (In Spanish).

Brusca, R. 1980. Common intertidal invertebrados of the Gulf of California. The University of Arizona Press, Arizona, USA, $571 \mathrm{pp}$.

Clores, M. A. and Ramos, G. B. 2013. Reproductive characteristics of the brachyuran crab, Grapsus tenuicrustatus (Decapoda: Grapsidae) found in Talim Bay, Batangas, Philippines. Arthropods, 2(3): 111-125.

Escamilla-Montes, R., De la Cruz-Aguero, G., Villalejo-Fuerte, M. T. and Diarte-Plata, G. 2013. Fertility of Callinectes arcuatus and $C$. bellicosus (Decapoda: Brachyura: Portunidae) in Ensenada La Paz, Gulf of California, Mexico. Universidad y Ciencia, 29(1): 53-61 (In Spanish).

Felix-Ortiz, J. A., Siu-Quevedo, E., Castaneda-Lomas, N., Rodriguez-Dominguez, G., Rodriguez-Montes de Oca, G. and Aragon-Noriega, E. A. 2014. Species composition and timing of peneid shrimp post-larvae (Decapoda: Peneidae) in the two zones of the Mexican Pacific Coast. Crustaceana, 87(7): 801-813.

Fernandez Sanchez, E. 2012. Effect of the opponent's colour on the aggressive behaviour of the Grapsus grapsus (Crustacea: Deacapoda). An. Univ. Etol., 6: 1-10 (In Spanish).

Flores-Campana, L. M., Ortiz-Arellano, M. and ArzolaGonzalez, J. F. 2003. Islands and islets. In: CifuentesLemus J. L. and Gaxiola-Lo Lopez, J. (Eds), Atlas of the ecosystems of Sinaloa, The College of Sinaloa, Mexico, p. 111-126 (In Spanish).

Flores-Campana, L. M., Gonzalez-Montoya, M. A., OrtizArellano, M. A. and Arzola-Gonzalez, J. F. 2007. Population structure of Chiton articulatus in the Pajaros and Venados islands of the Mazatlaan Bay, Sinaloa, Mexico. Rev. Mex. Biod., 78: 23S-31S (In Spanish). 
Flores-Campana, L. M., Arzola-Gonzalez, J. F., RamirezSoto, M. and Osorio-Perez, A. 2012. Impact of global climate change on the state of Sinaloa. Cuad. Geogr. Rev. Colomb. Geogr., 21: 115-129 (In Spanish).

Freire, A. S., Pinheiro, A. A., Karam-Silva, H. and Teschima, M. M. 2010. Biology of Grapsus grapsus (Linneaus, 1758) (Decapoda: Brachyura) in the Saint Peter and Saint Paul Archipelago, Equatorial, Atlantic Ocean. Helgol. Mar. Res., DOI 10.1007/510152-010-0220-5.

Guerrero, P. and Arana, P. 2009. Size structure and sexual maturity of the golden crab (Chenon chilensis) exploited off Robinson Crusoe Island, Chile. Lat. Am. J. Aquat. Res., 37: 347-360. DOI:10.3856/vol37-issue3-fulltext-6.

Gutierrez-Rubio, Y. 2015. Size structure, biometric relationships, fertility and growth of the rock crab Grapsus grapsus in the intertidal zone of the Lobos, Venados and Pajaros islands of the bay of Mazatlaan, Sinaloa. Mazatlaan. Masters Thesis, Faculty of Marine Sciences, Autonomous University of Sinaloa, Mexico (In Spanish).

Gutierrez-Rubio, Y., Perez-Gonzalez, R., Campos, E. and Arzola-Gonzalez, J. F. 2018. Size structure and biometric relationships of the rock crab Grapsus grapsus in the islands Lobos, Venados and Pajaros, Sinaloa, Mexico. Hidrobiologica, 28(1): 31-36. DOI: 10.24275/uam/izt/ dcbs/2018v28n1/Arzola (In Spanish).

Hendrickx, M., Brusca, R. and Findley, L. T. 2005. List and distribution of the macrofauna of the Gulf of California, Mexico, Part I, Invertebrates. Arizona-Sonora Desert Musseum, Arizona. 429 pp. (In Spanish).

Hattori, G. Y. and Pinheiro, M. A. 2001. Fecundity and embryology of Pachycheles monilifer (Anomura: Porcellanidae) at Praia Grande, Ubatuba, SP, Brazil. Nauplius, 9(2): 97-109.

Ortiz-Arellano, M. A. and Flores-Campana, L. F. 2008. Descriptive and illustrative catalog of molluscs in the intertidal zone of the islands of the bay of Navachiste, Sinaloa, Mexico. Autonomous University of Sinaloa, Sinaloa, Mexico, 157 pp (In Spanish)

Peiro, D. F. and Mantelatto, I. L. 2011. Population dynamics of pea crab Auxtinixa aidae (Brachyura, Pinnotheridae): a symbiotic of the ghost shrimp Callichirus major (Thalassinidea, Callianassidae) from the south-western Atlantic. Iheringia, Serie Zoologia, 101(1-2): 5-14 (In Spanish).
Puga-Lopez, D., Patino-Valencia, J. L., Hernandez-Cuvarrubias, V., Ulloa-Ramirez, P. A., Torres-Herrera, M. R. and PoncePalafox, J. T. 2015. Reproductive aspects of spiny lobster Panulirus spp. on the coasts of Nayarit, Mexico. Ciencia Pesquera, 23(1): 13-24 (In Spanish).

Ramirez Llodra, E. 2002. Fecundity and life history strategies in marine invertebrates. Adv. Mar. Biol., 43: 87-170. DOI:10.1016/S0065-2881(02)43004-0.

Rivera-Velazquez, P. Y., Aragon-Noriega, E. A., RodriguezDominguez, G., Perez-Gonzalez, R. and CastilloVargasmachuca, S. G. 2018. Growth, maturity and mortality of the blue crab Callinectes arcuatus (Decapoda: Portunidae) in a Mexican coastal lagoon. Crustaceana, 91(6): 659-675. DOI:org/10.1163/15685403-00003794.

Ricker, W. E. 1975. Computation and interpretation on biological statistics of fish populations. J. Fish. Res. Board Can., 191 $1-382$.

Rodriguez-Dominguez, G., Castillo-Vargasmanchuca, S., Perez-Gonzalez, R. and Aragon-Noriega A. E. 2012. Estimation of the individual growth parameters on the brown crab Callinectes bellicossus (Brachyura: Portunidae) using a multi-model approach. Crustaceana, 85(1): 55-69. DOI:10.1163/156854012X623700

Romero, L. 2003a. Reproductive behaviour and mutilations in the rock crab Grapsus grapsus (Crustacea: Decapoda). Rev. Peru Biol., 10(2): 195-202 (In Spanish).

Romero, L. 2003b. Observations on the social behaviour of the rock crab Grapsus grapsus. Rev. Peru Biol., 11(1): 112-119 (In Spanish).

Sanchez-Lindoro, F. J., Jimenez-Illescas, A. R., EspinozaCarrion, T. L. and Obeso-Nieblas, M. 2017. Hydrodynamic model in the Lagunar Navachiste system, Guasave, Sinaloa, Mexico. Rev. Biol. Mar. Oceanogr., 52(2): 219-231. DOI: 10.4067/S0718-19572017000200003 (In Spanish).

StatSoft 2004. Statisticsfor Windows, Manual ver. 7.0. StatSoft Inc., Tulsa, Oklahoma, USA.

Teschima, M. M., Aguiar, M. M., Farias, E., Meneses, B. S., Moreira, M. C., Pinheiro, M. A. and Freire, A. S. 2007. Fertility of the crab Grapsus grapsus in the Archipelago of Sao Pedro and Sao Paolo. In: Summaries of the VII LatinAmerican Congress of Sciences of the Sea.

Zar, J. H. 2009. Bioestatistical analysis, $3^{\text {rd }}$ edn. Prentice-Hall Inc., Upper Saddle River, USA, 960 pp. 